\title{
Front Matter: Volume 7149
}

, "Front Matter: Volume 7149," Proc. SPIE 7149, Multispectral, Hyperspectral, and Ultraspectral Remote Sensing Technology, Techniques, and Applications II, 714901 (17 December 2008); doi: 10.1117/12.821929 


\title{
PROCEEDINGS OF SPIE
}

\section{Multispectral, Hyperspectral, and Ultraspectral Remote Sensing Technology, Techniques, and Applications II}

\author{
Allen M. Larar \\ Mervyn J. Lynch \\ Makoto Suzuki \\ Editors
}

\section{8-20 November 2008 Noumea, New Caledonia}

Cosponsored by

Gouvernement de la Nouvelle-Calédonie (New Caledonia) • IRD—Institut de Recherche pour le Développement (France) • SPC - Secretariat of the Pacific Community •ISRO-Indian Space Research Organization (India) - NASA-National Aeronautics and Space Administration (United States) - Scripps Institution of Oceanography, University of California, San Diego (United States) - Secretariat Permanent pour le Pacifique, République Française (France) • JAXA_Japan Aerospace Exploration Agency (Japan) • NiCT-National Institute of Information and Communications Technology (Japan) NOAA-National Oceanic and Atmospheric Administration (United States)

\section{Cooperating Organizations}

CCG_-International Ocean Colour Coordinating Group • IFREMER—Institut Français de Recherche pour l'Exploitation de la Mer (France) • Université de la Nouvelle-Calédonie (New Caledonia) SOPAC-Pacific Islands Applied Geoscience Commission

Published by

SPIE

Volume 7149 
The papers included in this volume were part of the technical conference cited on the cover and title page. Papers were selected and subject to review by the editors and conference program committee. Some conference presentations may not be available for publication. The papers published in these proceedings reflect the work and thoughts of the authors and are published herein as submitted. The publisher is not responsible for the validity of the information or for any outcomes resulting from reliance thereon.

Please use the following format to cite material from this book:

Author(s), "Title of Paper," in Multispectral, Hyperspectral, and Ultraspectral Remote Sensing Technology, Techniques, and Applications II, edited by Allen M. Larar, Mervyn J. Lynch, Makoto Suzuki, Proceedings of SPIE Vol. 7149 (SPIE, Bellingham, WA, 2008) Article CID Number.

ISSN 0277-786X

ISBN 9780819473912

Published by

SPIE

P.O. Box 10, Bellingham, Washington $98227-0010$ USA

Telephone +1 3606763290 (Pacific Time) · Fax +1 3606471445

SPIE.org

Copyright (C) 2008, Society of Photo-Optical Instrumentation Engineers

Copying of material in this book for internal or personal use, or for the internal or personal use of specific clients, beyond the fair use provisions granted by the U.S. Copyright Law is authorized by SPIE subject to payment of copying fees. The Transactional Reporting Service base fee for this volume is $\$ 18.00$ per article (or portion thereof), which should be paid directly to the Copyright Clearance Center (CCC), 222 Rosewood Drive, Danvers, MA 01923. Payment may also be made electronically through CCC Online at copyright.com. Other copying for republication, resale, advertising or promotion, or any form of systematic or multiple reproduction of any material in this book is prohibited except with permission in writing from the publisher. The CCC fee code is 0277-786X/08/\$18.00.

Printed in the United States of America.

Publication of record for individual papers is online in the SPIE Digital Library.

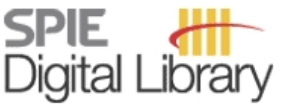

SPIEDigitalLibrary.org

Paper Numbering: Proceedings of SPIE follow an e-First publication model, with papers published first online and then in print and on CD-ROM. Papers are published as they are submitted and meet publication criteria. A unique, consistent, permanent citation identifier (CID) number is assigned to each article at the time of the first publication. Utilization of CIDs allows articles to be fully citable as soon they are published online, and connects the same identifier to all online, print, and electronic versions of the publication. SPIE uses a six-digit CID article numbering system in which:

- The first four digits correspond to the SPIE volume number.

- The last two digits indicate publication order within the volume using a Base 36 numbering system employing both numerals and letters. These two-number sets start with 00, 01, 02, 03, 04 , 05, 06, 07, 08, 09, OA, OB ... 0Z, followed by 10-1Z, 20-2Z, etc.

The CID number appears on each page of the manuscript. The complete citation is used on the first page, and an abbreviated version on subsequent pages. Numbers in the index correspond to the last two digits of the six-digit CID number. 


\title{
Contents
}

\author{
vii Conference Committee \\ ix Symposium Committees \\ xi Introduction
}

\section{SESSION 1 GEOPHYSICAL RETRIEVALS, INFORMATION CONTENT, AND DATA ASSIMILATION}

714902 Ultra-spectral remote sounding: background and future (Invited Paper) [7149-01]

W. Smith, Sr., Univ. of Wisconsin, Madison (United States) and Hampton Univ. (United States);

H. Revercomb, H. Woolf, H. Huang, Univ. of Wisconsin, Madison (United States); A. Larar,

D. Zhou, NASA Langley Research Ctr. (United States); S. Kireev, Hampton Univ. (United

States); J. Tian, X. Liu, NASA Langley Research Ctr. (United States)

714903 The use of hyperspectral data in numerical weather prediction [7149-02]

J. Le Marshall, Bureau of Meteorology (Australia) and Joint Ctr. for Satellite Data Assimilation (United States); J. Jung, Joint Ctr. for Satellite Data Assimilation (United States) and Univ. of Wisconsin , Madison (United States); L. Bi, Univ. of Wisconsin, Madison (United States)

714905 Neural network estimation of atmospheric profiles using AIRS/IASI/AMSU data in the presence of clouds [7149-05]

W. J. Blackwell, M. Pieper, L. G. Jairam, MIT Lincoln Lab. (United States)

714906 The profile retrieval scheme of FY3A sounding suite [7149-06]

X. WU, P. Zhang, F. Zhang, C. Qi, Q. Lu, National Satellite Meteorological Ctr. (China)

714907 Retrieval research on pixel-level 3D humidity fields by using GMS multispectral imagery [7149-07]

F. YU, Nanjing Univ. (China)

714908 Simulations for observation of tropospheric pollutants using infrared spectroscopy from geostationary orbit [7149-09]

K. Sagi, Ibaraki Univ. (Japan) and National Institute of Information and Communications Technology (Japan); E. Dupuy, National Institute of Information and Communications Technology (Japan); K. Suzuki, Tokyo Gakugei Univ. (Japan); P. Baron, Y. Kasai, National Institute of Information and Communications Technology (Japan); K. Kita, Ibaraki Univ. (Japan); R. Imasu, Univ. of Tokyo (Japan)

714909 Tropospheric water vapor retrieval from a nadir THz/FIR sounder [7149-10] P. Baron, J. Mendrok, E. Dupuy, Y. Kasai, National Institute of Information and Communications Technology (Japan) 
7149 OA NPOESS Preparatory Project (NPP): Cross-track Infrared Microwave Sounder Sensors (CrIMSS) characterization and performance validation plan (Invited Paper) [7149-11] G. E. Bingham, C. Fish, V. V. Zavyalov, Space Dynamics Lab. (United States); C. D. Barnet, NOAA/NESDIS/STAR (United States)

7149 OB Radiometric calibration accuracy of GOSAT-TANSO-FTS (TIR) relating to $\mathrm{CO}_{2}$ retrieval error [7149-12]

R. Imasu, N. Saitoh, Y. Niwa, The Univ. of Tokyo (Japan); H. Suto, A. Kuze, K. Shiomi, M. Nakajima, Japan Aerospace Exploration Agency (Japan)

7149 OC Radiometric modeling and calibration of the Geostationary Imaging Fourier Transform Spectrometer (GIFTS) ground based measurement experiment [7149-13] J. Tian, NASA Langley Research Ctr. (United States); W. L. Smith, Hampton Univ. (USA) and Univ. of Wisconsin, Madison (United States); M. J. Gazarik, NASA Langley Research Ctr. (United States)

7149 OF Comparison of spectral transmittance degradation due to organic gas contamination with on-orbit degradations of launched sensors [7149-16]

N. Itoh, Mie Univ. (Japan); M. Katoh, N. Okano, Univ. of Tokushima (Japan)

\section{SESSION 3 FUTURE ADVANCED SATELLITE SENSORS}

7149 OM Hyperspectral sensor HSC3000 for nano-satellite TAIKI [7149-24]

S. Satori, Y. Aoyanagi, Hokkaido Institute of Technology (Japan); U. Hara, Dense, Inc. (Japan); R. Mitsuhashi, Hokkaido Institute of Technology (Japan); Y. Takeuchi, Hokkaido Satellite, Inc. (Japan)

7149 ON Prototype development of a compact imaging spectrometer (COMIS) for a microsatellite, STSAT3 [7149-25]

J. H. Lee, Kongju National Univ. (Republic of Korea); Y. M. Kim, Mirae Corp. (Republic of Korea); T. Jang, KAIST (Republic of Korea); H. Yang, Korea Research Institute of Standards and Science (Republic of Korea); K. I. Kang, KAIST (Republic of Korea); S. W. Rhee, Korea Aerospace Research Institute (Republic of Korea)

\section{SESSION 4 IMAGE CLASSIFICATION AND CHANGE DETECTION}

714900 A case study on an improved method for very high spatial resolution satellite image classification: watersheds across the complex environment of high Pacific islands [7149-26] M. Despinoy, M. Aubert, M. Barotin, Institut de Recherche pour le Développement (New Caledonia); M. Mangeas, Univ. of New Caledonia (New Caledonia)

7149 OS Cloud classification by using multi-spectral GMS imagery and comparison with surface cloud observation [7149-30]

F. YU, H. Shao, Nanjing Univ. (China) 
7149 OT A method for detecting change in coral reef using pan-sharpened satellite images [7149-31]

H. Hanaizumi, M. Akiba, Hosei Univ. (Japan); H. Yamano, T. Matsunaga, National Institute for Environmental Studies (Japan)

\section{SESSION $5 \quad$ REMOTE SENSING SYSTEM APPLICATIONS}

7149 OY Correlation between $\mathrm{SO}_{2}$ emissions rate and $\mathrm{S}$ contained in fuel used in a power plant, Noumea, New Caledonia [7149-37]

P. Bani, Univ. de la Nouvelle Calédonie (New Caledonia) and IRD-Nouméa (New Caledonia); C. Oppenheimer, V. Tsanev, Univ. of Cambridge (United Kingdom); M. Lardy, IRD-Nouméa (New Caledonia); T. Hoibian, M. Allenbach, I. Rouet, Univ. de la Nouvelle Calédonie (New Caledonia)

$71490 Z$ Development of a terawatt coherent white light lidar system and applications to environmental studies [7149-38]

C. Yamanaka, Osaka Univ. (Japan); T. Somekawa, Osaka Univ. (Japan) and Institute for Laser Technology (Japan); M. C. Galvez, De La Salle Univ. (Philippines); M. Fujita, Institute for Laser Technology (Japan)

\section{INTERACTIVE POSTER SESSION}

714917 A study of predictability of SST at different time scales based on satellite time [7149-45] Y. Ding, Nanjing Univ. of Science and Technology (China) and State Oceanic Administration (China); D. Fu, State Oceanic Administration (China); Z. Wei, Nanjing Univ. of Science and Technology (China); X. He, H. Huang, D. Pan, State Oceanic Administration (China)

714918 Inversion study of rainfall intensity field at all time during Mei-Yu period by using MTSAT multi-spectral imagery [7149-46]

C. Wang, F. YU, Y. Zhao, Nanjing Univ. (China)

714919 The effect of nonuniform vertical profiles of chlorophyll concentration on apparent optical properties [7149-47]

Y. Xi, K. Du, L. Sun, Beijing Normal Univ. (China); Z. Lee, Mississippi State Univ. (United States)

7149 1A Development and application of Nanji Islands biodiversity geographical information system [7149-48]

H. Zhang, State Oceanic Administration (China) and Ocean Univ. of China (China); W. Huang, J. Yang, B. Fu, D. Li, State Oceanic Administration (China)

7149 1D Multidirectional visible and shortwave infrared polarimeter for atmospheric aerosol and cloud observation: OSIRIS (Observing System Including PolaRisation in the Solar Infrared Spectrum) [7149-51]

F. Auriol, J.-F. Léon, J.-Y. Balois, C. Verwaerde, P. François, J. Riedi, F. Parol, F. Waquet,

D. Tanré, P. Goloub, Lab. d'Optique Atmosphérique, CNRS, Univ. des Sciences et Technologies de Lille 1 (France) 
7149 lE A spatial Poisson Point Process to classify coconut fields on lkonos pansharpened images [7149-52]

R. Teina, D. Béréziat, Univ. Pierre et Marie Curie (France); B. Stoll, Univ. de la Polynésie Française (French Polynesia)

Author Index

vi

Downloaded From: https://www.spiedigitallibrary.org/conference-proceedings-of-spie on 26 Apr 2023 Terms of Use: https://www.spiedigitallibrary.org/terms-of-use 


\title{
Conference Committee
}

\author{
Conference Chairs
}

Allen M. Larar, NASA Langley Research Center (United States)

Mervyn J. Lynch, Curtin University of Technology (Australia)

Makoto Suzuki, Japan Aerospace Exploration Agency (Japan)

Program Committee

Gail E. Bingham, Utah State University (United States)

Hyo-Sang Chung, Chosun University (Republic of Korea) and Korean

Aerospace Research Institute (Republic of Korea)

Yoshiaki Honda, Chiba University (Japan)

Ryoichi Imasu, The University of Tokyo (Japan)

John F. Le Marshall, Bureau of Meteorology (Australia)

Thomas S. Pagano, Jet Propulsion Laboratory (United States)

Jeffery J. Puschell, Raytheon Space and Airborne Systems (United

States)

Henry E. Revercomb, University of Wisconsin, Madison (United States)

William L. Smith, Sr., Hampton University (United States)

Jianyu Wang, Shanghai Institute of Technical Physics (China)

\section{Session Chairs}

1 Geophysical Retrievals, Information Content, and Data Assimilation

Allen M. Larar, NASA Langley Research Center (United States)

2 Sensor Performance, Calibration, and Validation

Henry E. Revercomb, University of Wisconsin, Madison (United States)

3 Future Advanced Satellite Sensors

Makoto Suzuki, Japan Aerospace Exploration Agency (Japan)

$4 \quad$ Image Classification and Change Detection

Ryoichi Imasu, The University of Tokyo (Japan)

$5 \quad$ Remote Sensing System Applications

Ryoichi Imasu, The University of Tokyo (Japan) 
Downloaded From: https://www.spiedigitallibrary.org/conference-proceedings-of-spie on 26 Apr 2023

Terms of Use: https://www.spiedigitallibrary.org/terms-of-use 


\title{
Symposium Committees
}

\author{
Symposium General Chairs
}

Upendra N. Singh, NASA Langley Research Center (United States)

Robert J. Frouin, Scripps Institution of Oceanography, University of California, San Diego (United States)

Frederic Guillard, Government of New Caledonia (New Caledonia)

Symposium General Cochairs

Hiroshi Kumagai, National Institute of Information and Communications Technology (Japan)

A. S. Kiran Kumar, Indian Space Research Organisation (India)

Delu Pan, State Oceanic Administration (China)

Symposium Honorary Chairs

Michael Freilich, NASA Headquarters (United States)

Mary Ellen Kicza, NOAA-National Oceanic and Atmospheric Administration (United States)

Fabrice Colin, Institut de Recherche pour le Développement (New Caledonia)

Yasushi Horikawa, Japan Aerospace Exploration Agency (Japan)

G. Madhavan Nair, Indian Space Research Organisation (India)

Shuguang Wang, Chinese Society of Oceanography (China)

Symposium Honorary Cochairs

Jimmie Rodgers, Secretariat of the Pacific Communities

Lionel Loubersac, Institut Français de Recherche pour L'Exploitation de la Mer (New Caledonia)

Jean-Claude Angue, French Ministry of Research and Technology (New Caledonia)

Symposium Technical Program Chairs

William L. Smith, Hampton University (United States)

Morgan Mangeas, Université de la Nouvelle-Calédonie (New Caledonia)

Kohei Mizutani, National Institute of Information and Communications Technology (Japan)

Vaddadi Jayaraman, Indian Space Research Organisation (India)

Chuqun Chen, South China Sea Institute of Oceanology (China)

Symposium Steering Committee

Chair: Upendra Singh, NASA Langley Research Center (United States)

Cochair: George J. Komar, NASA Goddard Space Flight Center (United States) 
Kazuhiro Asai, Tohoku Institute of Technology (Japan)

Robert Frouin, Scripps Institution of Oceanography, University of California, San Diego (United States)

Frederic Guillard, Government of New Caledonia (New Caledonia)

Toshikazu Itabe, National Institute of Information and Communications Technology (Japan)

Achuthan Jayaraman, Physical Research Laboratory (India)

Jack A. Kaye, NASA Headquarters (United States)

A. S. Kiran Kumar, Indian Space Research Organisation (India) Stephen A. Mango, NOAA National Polar-orbiting Operational Environmental Satellite System (United States)

Takashi Moriyama, Japan Aerospace Exploration Agency (Japan)

Delu Pan, State Oceanic Administration (China)

Stephen P. Sandford, NASA Langley Research Center (United States)

Jinxue Wang, Raytheon Company (United States)

Symposium International Organizing Committee

Yu-Hwan Ahn, Korea Ocean Research and Development Institute

(Republic of Korea)

Jinyu Cheng, Chinese Society of Oceanography (China)

Adarsh Deepak, Science and Technology Corporation (United States)

Franco Einaudi, NASA Goddard Space Flight Center (United States)

Wolf Forstreuter, Pacific Islands Applied Geoscience Commission

Ramesh Kakar, NASA Headquarters (United States)

Yves Lafoy, Regional Cooperation Department of New Caledonia (New Caledonia)

Mervyn J. Lynch, Curtin University of Technology (Australia)

Shailesh R. Nayak, Indian Space Research Organisation (India)

Haruhisa Shimoda, Japan Aerospace Exploration Agency (Japan)

Lelia B. Vann, NASA Langley Research Center (United States)

Yoshifumi Yasuoka, The University of Tokyo (Japan)

James R. Yoder, Woods Hole Oceanographic Institution (United States)

Local Organizing Committee

Yann-Eric Boyeau, Government of New Caledonia (New Caledonia)

Damien Buisson, Government of New Caledonia (New Caledonia)

Marc Despinoy, Institut de Recherche pour le Développement (New

Caledonia)

Morgan Mangeas, Université de la Nouvelle-Calédonie (New Caledonia) 


\section{Introduction}

Accurately calibrated multi-, hyper-, and ultra-spectral remote sensing measurement systems are rapidly becoming the instruments of choice for observing a wide variety of geophysical variables from ground-, aircraft-, and satellite-based platforms. New data processing and analysis techniques are emerging for the optimum interpretation of resultant radiance measurements obtained by these spectrometer systems, covering a spectral range from the visible to the far infrared, to enable a wide range of research and operational applications; geophysical applications include, for example, surface and cloud property characterizations along with retrievals of atmospheric state, dynamics, and composition, all at high spatial resolution while simultaneously covering large areas. Geophysical remote sensing data products from multi- to ultra-spectral remote sensing systems promise to accelerate scientific research on environmental processes, enable efficient monitoring of environmental variables, and lead to improved predictive capability for such parameters and how they respond to natural and anthropogenic external forcings. New and improved technologies and techniques promise smaller and lighter next-generation sensor systems for enhancing current and enabling new future measurement capabilities.

The Multispectral, Hyperspectral, and Ultraspectral Remote Sensing Technology, Techniques, and Applications II conference was run within SPIE's Sixth International Asia-Pacific Symposium on Remote Sensing of the Atmosphere, Environment, and Space, held in Noumea, New Caledonia, 17-21 November, 2008. The objective of this conference was to bring together the scientific, engineering, and data user communities to provide an international forum for exchanging information about the development, application of, and experimental results from multi-, hyperand ultra-spectral resolution remote sensing measurement systems. Primary focus areas were associated with the design, development, and implementation of, as well as analysis and usage of data from, such remote sensing systems intended for environmental monitoring applications. The conference was very successful with approximately 35 oral and poster presentations delivered from authors of diverse international affiliations (i.e., United States, Japan, China, New Caledonia, Australia, South Korea, France, and Pakistan). The conference presentation structure was composed of five oral and one poster sessions. Several of the oral presentations had different aspects of their topical areas also covered in the poster session. The first oral session of this conference focused on geophysical retrievals, information content, and data assimilation. The second session addressed sensor performance, calibration, and validation. The third and fourth sessions concentrated on future advanced satellite sensors, and image classification and change detection, respectively. The fifth and final oral session focused on remote sensing system applications.

We would like to express our sincere appreciation to the program committee and session chairs, to colleagues who participated in the conference, to the SPIE staff, and to all our hosts and meeting sponsors in Noumea whose contributions were all essential to the success of this conference.

\footnotetext{
Allen M. Larar Mervyn J. Lynch Makoto Suzuki
} 
Downloaded From: https://www.spiedigitallibrary.org/conference-proceedings-of-spie on 26 Apr 2023

Terms of Use: https://www.spiedigitallibrary.org/terms-of-use 